\title{
Synthesis, Structural Study and Biological Activity of Bridgehead Nitrogen Containing Triazolo-thiadiazine Derivatives
}

\author{
PRADIP P. DEOHATE
}

P. G. Department of Chemistry, Shri Radhakisan Laxminarayan Toshniwal College of Science, Akola-444001, India pradip222091@yahoo.co.in

Received 25 September 2012 / Accepted 19 October 2012

\begin{abstract}
A facile synthesis of 6,7-di-[substituted]-phenyl-3-pyridin-4-yl-5 $H$-[1,2,4]-triazolo-[3,4-b][1,3,4]-thiadiazines have been carried out by reacting 4-amino-3-mercapto-5-pyridin-4-yl-4H-[1,2,4]triazole with substituted benzoins in presence of potassium hydroxide. The required 4-amino-3mercapto-5-pyridin-4-yl-4H-[1,2,4]-triazole was synthesized by reacting isoniazide with carbondisulphide and potassium hydroxide followed by the addition of hydrazine hydrate. The acetylation of triazolo-thiadiazines afforded monoacetyl derivatives. The constitution of synthesized compounds have been delineated on the basis of chemical transformation, elemental analysis, equivalent weight determination and IR, ${ }^{1} \mathrm{H}$ NMR spectral studies. The title compounds have been assayed for their biological activity against gram-positive as well as gram-negative microorgansms.
\end{abstract}

Keywords: Synthesis, Biological activity, Triazolo-thiadiazines

\section{Introduction}

The heterocyclic compounds and especially those containing sulphur and nitrogen atoms possess a wide variety of biological activities ${ }^{1,2}$. Therapeutic effect of 1,2,4-triazole and 1,2,4-triazole-3-one containing compounds have been well studied for a number of pathological conditions including inflammation, cancer, pain, tuberculosis and hypertension $^{3,4} \cdot 1,2,4$-Triazoles fused with 1,3,4-thiadiazines are found to possess diverse applications in the field of medicine ${ }^{5,6}$. Triazolo-thiadiazines are reported to show a broad spectrum of pharmacologicallly important properties like antifungal ${ }^{7}$, antibacterial ${ }^{8}$, antiviral $^{9}$, anthelmentic ${ }^{10}$, antitumor ${ }^{11}$, anti-inflammatory ${ }^{12}$, antituberculor ${ }^{13}$, diuretics ${ }^{14}$, anticancer ${ }^{15}$ and hypoglycaemic agents ${ }^{16}$. These two fused systems are reported to possess significant CNS depressant, herbicidal, anthelmintic activities and have been widely used in pharmaceutical and agrochemical industry ${ }^{17}$. In view of these findings about the utility of fused heterocyclic compounds in various fields and as a part of wider programme to provide alternative routes for the synthesis of 5 and 6 membered heterocyclic compounds ${ }^{18-20}$, we report herein the synthesis of substituted-[1,2,4]-triazolo-[3,4-b]-[1,3,4]-thiadiazines. 


\section{Experimental}

The melting points of all synthesized compounds were recorded using hot paraffin-bath and are uncorrected. Chemicals used were of AR grade. ${ }^{1} \mathrm{H}$ NMR spectra were recorded with TMS as internal standard using $\mathrm{CDCl}_{3}$ and DMSO- $d_{6}$ as solvents. IR spectra were recorded on Perkin-Elmer spectrophotometer in the range $4000-400 \mathrm{~cm}^{-1}$ in nujol mull and as $\mathrm{KBr}$ pellete. Purity of the compounds was checked on silica gel-G plates by TLC. The substituted benzoins were prepared by the procedure described in Vogel's text book of practical organic chemistry.

\section{Synthesis of 4-amino-3-mercapto-5-pyridin-4-yl-4H-[1,2,4]-triazole (2)}

The compound 4-amino-3-mercapto-5-pyridin-4-yl-4H-[1,2,4]-triazole (2) was prepared by the interaction of isoniazide 1 ( 0.01 mole) with carbondisulphide ( 0.01 mole) and potassium hydroxide (1 mole, $10 \mathrm{~mL}$ ) followed by the drop wise addition of hydrazine hydrate (0.01 mole) with constant stirring. The stirring was continued for 30 minutes at room temperature. The reaction mixture was cooled and poured in distilled water, a white precipitate was obtained. It was washed with water and recrystallized from ethanol, 2 (85\%), m.p. $145{ }^{0}$ C. (Found: C, 43.11; H, 3.31; N, 35.82; S, 16.08. Calcd. for $\mathrm{C}_{7} \mathrm{H}_{7} \mathrm{~N}_{5} \mathrm{~S}$ : C, 43.52; H, 3.62; N, 36.26; S, 16.58\%); $v_{\max }$ 3423, $3370(\mathrm{NH}), 1682(\mathrm{C}=\mathrm{N}), 1298(\mathrm{C}-\mathrm{N}), 1210(\mathrm{~N}-\mathrm{N})$, $758 \mathrm{~cm}^{-1}(\mathrm{C}-\mathrm{S})^{25,26}$.

\section{Synthesis of 6,7-diphenyl-3-pyridin-4-yl-5H-[1,2,4]-triazolo-[3,4-b]-[1,3,4]- thiadiazine (4a)}

The mixture of 4-amino-3-mercapto-5-pyridin-4-yl-4H-[1,2,4]-triazole 2 (0.01 mole) and 2-hydroxy-1,2-diphenyl-ethanone (benzoin) (0.01 mole) in $\mathrm{KOH} \mathrm{(1} \mathrm{M,} 10 \mathrm{~mL}$ ) was refluxed in $15 \mathrm{~mL}$ ethanol for $1.5 \mathrm{~h}$. The reaction mixture was cooled and poured in distilled water, white coloured precipitate was obtained. It was crystallized from aqueous ethanol and identified as 6,7-diphenyl-3-pyridin-4-yl-5H-[1,2,4]-triazolo-[3,4-b]-[1,3,4]-thiadiazine $\quad 4 a \quad$ (80\%), m.p. $120{ }^{\circ} \mathrm{C}$. (Found: C, 67.96; H, 4.02; N, 18.88; S, 8.57. Calcd. for $\mathrm{C}_{21} \mathrm{H}_{15} \mathrm{~N}_{5} \mathrm{~S}$ : C, 68.29; H, 4.06; N, 18.97; S, 8.67\%); $v_{\max } 3378(\mathrm{NH}), 1679(\mathrm{C}=\mathrm{N}), 1306(\mathrm{C}-\mathrm{N}), 1205(\mathrm{~N}-\mathrm{N}), 754 \mathrm{~cm}^{-1}(\mathrm{C}-\mathrm{S}) ; \delta$ $\left(\mathrm{CDCl}_{3}+\mathrm{DMSO}-d_{6}\right)$ 5.88-8.06 $(14 \mathrm{H}, \mathrm{m}, \mathrm{Ar}-\mathrm{H}), 3.36(1 \mathrm{H}, \mathrm{s}, \mathrm{NH})$. This reaction was extended to synthesize other compounds $\mathbf{4 b - f :} \mathbf{4 b}(65 \%)$, m.p.125 ${ }^{0} \mathrm{C}$ (Found: C, 62.55; H, 3.65; N, 17.12; S, 7.71. Calcd. for $\mathrm{C}_{21} \mathrm{H}_{15} \mathrm{~N}_{5} \mathrm{O}_{2} \mathrm{~S}$ : C, 62.84; H, 3.74; N, 17.45; S, 7.98\%); $v_{\max } 3512$ (OH), $3386(\mathrm{NH}), 1678(\mathrm{C}=\mathrm{N}), 1316(\mathrm{C}-\mathrm{O}), 1302(\mathrm{C}-\mathrm{N}), 1208(\mathrm{~N}-\mathrm{N}), 758 \mathrm{~cm}^{-1}(\mathrm{C}-\mathrm{S}) ; \delta$ $\left(\mathrm{CDCl}_{3}+\mathrm{DMSO}-d_{6}\right) 8.43$ (2H, s, OH), 5.94-8.06 (12H, m, Ar-H), $3.41(1 \mathrm{H}, \mathrm{s}, \mathrm{NH}) ; 4 \mathrm{c}(70 \%)$, m.p. $108{ }^{0} \mathrm{C}$ (Found: C, 62.63; H, 3.54; N, 17.31; S, 7.85. Calcd. for $\mathrm{C}_{21} \mathrm{H}_{15} \mathrm{~N}_{5} \mathrm{O}_{2} \mathrm{~S}: \mathrm{C}, 62.84$; H, 3.74; N, 17.45; S, 7.98\%); 4d (75\%), m.p. $96{ }^{0} \mathrm{C}$ (Found: C, 56.93; H, 2.95; N, 15.84; S, 7.21. Calcd. for $\mathrm{C}_{21} \mathrm{H}_{13} \mathrm{~N}_{5} \mathrm{SCl}_{2}$ : C, 57.66; H, 2.97; N, 16.00; S, 7.32\%); 4e (77\%), m.p. $164{ }^{0} \mathrm{C}$ (Found: C, 64.02; H, 4.29; N, 15.95; S,7.28. Calcd. for $\mathrm{C}_{23} \mathrm{H}_{19} \mathrm{~N}_{5} \mathrm{O}_{2} \mathrm{~S}$ : C, 64.33; H, 4.42; N, 16.31; S, 7.45\%); 4f (76\%), m.p. $152{ }^{0} \mathrm{C}$ (Found: C, 59.11; H, 3.99; N, 15.06; S, 6.77. Calcd. for $\mathrm{C}_{23} \mathrm{H}_{19} \mathrm{~N}_{5} \mathrm{O}_{4} \mathrm{~S}$ : C, 59.86; H, 4.12; N, 15.18; S, 6.94\%).

Synthesis of 5-acetyl-6,7-diphenyl-3-pyridin-4-yl-5H-[1,2,4]-triazolo-[3,4-b]-[1,3,4]thiadiazine (5a)

A mixture of 6,7-diphenyl-3-pyridin-4-yl-5 $H$-[1,2,4]-triazolo-[3,4-b]-[1,3,4]-thiadiazine (4a) $(0.01 \mathrm{~mol})$ and acetic anhydride $(0.01 \mathrm{~mol})$ in glacial acetic acid $(10 \mathrm{~mL})$ was refluxed for $2.5 \mathrm{~h}$. The reaction mixture was cooled and poured in a little crushed ice with water, a cream coloured solid precipitated was crystallised from aqueous ethanol to give $5 \mathbf{a}$ (76\%), m.p.139 ${ }^{0} \mathrm{C}$ (Found: C, 65.77; H, 3.97; N, 16.98; S, 7.62. Calcd. for $\mathrm{C}_{23} \mathrm{H}_{17} \mathrm{~N}_{5} \mathrm{OS}$ : C, 67.15; H, 4.13; N, 
17.03; S, 7.78\%); $v_{\max } 1689(\mathrm{C}=\mathrm{O}), 1682(\mathrm{C}=\mathrm{N}), 1297(\mathrm{C}-\mathrm{N}), 1213(\mathrm{~N}-\mathrm{N}), 754 \mathrm{~cm}^{-1}(\mathrm{C}-\mathrm{S}) ; \delta$ $\left(\mathrm{CDCl}_{3}+\mathrm{DMSO}_{6}\right)$ 5.88-8.06 $(14 \mathrm{H}, \mathrm{m}, \mathrm{Ar}-\mathrm{H}), 2.43\left(3 \mathrm{H}, \mathrm{s}, \mathrm{CO}-\mathrm{CH}_{3}\right)$. This reaction was extended to synthesize other acetyl derivatives $\mathbf{5 b}$-f from $\mathbf{4 b}$-f respectively: $\mathbf{5 b}(70 \%)$, m.p. $132{ }^{0} \mathrm{C}$; 5c (74\%), m.p. $124{ }^{0} \mathrm{C}$; $5 \mathbf{d}(70 \%)$, m.p. $119{ }^{0} \mathrm{C}$; 5e (68\%), m.p. $151{ }^{0} \mathrm{C} ; \mathbf{5 f}(75 \%)$, m.p. $138{ }^{0} \mathrm{C}$.

\section{Results and Discussion}

The parent compound 4-amino-3-mercapto-5-pyridin-4-yl-4H-[1,2,4]-triazole (2) was prepared by the interaction of isoniazide 1 ( 0.01 mole) with carbondisulphide $(0.01$ mole) and potassium hydroxide ( 1 mole, $10 \mathrm{~mL}$ ) followed by the dropwise addition of hydrazine hydrate (0.01 mole) with constant stirring. It was transformed into 6,7-di-[substituted]phenyl-3-pyridin-4-yl-5H-[1,2,4]-triazolo-[3,4-b]-[1,3,4]-thiadiazines $4 a-f$ by condensing it with substituted benzoins 3a-f $(0.01$ mole) in presence of $\mathrm{KOH}(1 \mathrm{M}, 10 \mathrm{~mL})$ using ethanol as a solvent for $1.5 \mathrm{~h}$. The reaction mixture was cooled and poured in distilled water. The resulting white precipitate was crystallized from aqueous ethanol. Compounds 4a-f on acylation with mixture acetic anhydride and glacial acetic acid afforded monoacetyl derivatives 5a-f. (Scheme 1)<smiles>NNC(=O)c1ccncc1</smiles>

Where,<smiles>[132I][123I]c1ccccc1</smiles>

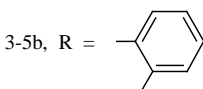
HO<smiles></smiles><smiles>Nn1c(S)nnc1-c1ccncc1</smiles><smiles>[18O]=Cc1ccc(Cl)cc1</smiles>

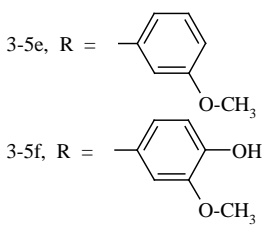<smiles>[R]C1=C(C(C)=O)Nn2c(nnc2-c2ccncc2)S1</smiles><smiles></smiles>

Scheme 1 


\section{Antimicrobial activity}

The synthesized compounds 4a-f were screened for their antibacterial activity using cup plate diffusion method ${ }^{21,22}$. The bacterial organisms used included both gram-positive as well as gram-negative strains like E. coli, S. aureus, S. typhi, B. subtilis and A. aerogenes. Sensitivity plates were seeded with a bacterial innoculum of $1 \times 10^{6} \mathrm{CIU} \mathrm{mL}^{-1}$ and each well (diameter $10 \mathrm{~mm}$ ) was loaded with $0.1 \mathrm{~mL}$ of test compound solution $\left(1000 \mu \mathrm{g} \mathrm{mL}^{-1}\right)$ in DMF, so that concentration of each test compound was $100 \mu \mathrm{gL}^{-1}$. The zones of inhibition were recorded after incubation for $24 \mathrm{~h}$ at $37{ }^{\circ} \mathrm{C}$, using Vernier caliper. Inhibition zone record of the compounds clearly indicated that $\mathbf{4 b}, \mathbf{4 e}$ and $\mathbf{4 f}$ were highly active against E. coli, S. aureus, S. typhi and moderately active against $A$. aerogenes. Majority of the compounds were found inactive against $B$. subtilis (Table 1).

To determine minimum inhibitory concentration (MIC), the serial dilution technique ${ }^{23}$ was followed using nutrient broth medium. The MIC values of compounds $\mathbf{4 b}, \mathbf{4 e}$ and $\mathbf{4 f}$, were determined against E. coli, S. aureus and S. typhi, which were found to be 85,82 and $78 \mu \mathrm{g} \mathrm{mL}^{-1}$ respectively.

Screening of these compounds $4 a-\mathbf{a}$ having the concentration $1 \%$, for antifungal activity using paper disc method ${ }^{24}$ showed that $\mathbf{4 b}, \mathbf{4} \mathbf{c}$ and $\mathbf{4 f}$ were highly active against $A$. niger, whereas other compounds showed low to moderate activity. The zones of inhibition were recorded after incubation for $48 \mathrm{~h}$ at $37{ }^{0} \mathrm{C}$ (Table 1 ).

Table 1. Antibacterial and antifungal activity of compounds 4a-f

\begin{tabular}{|c|c|c|c|c|c|c|}
\hline \multirow{2}{*}{ Compounds } & \multicolumn{5}{|c|}{ Antibacterial activity } & \multirow{2}{*}{$\begin{array}{c}\begin{array}{c}\text { Antifungal } \\
\text { activity }\end{array} \\
\text { A. niger } \\
\text { (Conc. 1\%) }\end{array}$} \\
\hline & E. coli & S. aureus & $\begin{array}{c}\text { S. } \\
\text { typhi }\end{array}$ & $\begin{array}{c}\text { B. } \\
\text { subtilis }\end{array}$ & $\begin{array}{c}A . \\
\text { aerogenes }\end{array}$ & \\
\hline $4 a$ & + & ++ & + & - & + & - \\
\hline $4 b$ & +++ & +++ & +++ & + & ++ & +++ \\
\hline 4c & + & + & - & - & + & +++ \\
\hline 4d & - & + & ++ & - & - & + \\
\hline $4 e$ & +++ & +++ & +++ & + & ++ & + \\
\hline 4f & +++ & +++ & +++ & - & ++ & +++ \\
\hline
\end{tabular}

(-): Inactive (12 mm and less), (+): Weakly active (13-16 mm), (++): Moderately active (17-20 mm), $(+++)$ : Highly active (21 $\mathrm{mm}$ and above)

\section{Acknowledgement}

Thanks are due to Director, R.S.I.C., Central Drug Research Institute, Chandigarh for providing analytical and spectral data. Author is thankful to Ms. Bhagyashree M. Sonkusare and Ms. Vaishali R. Patil for their generous help during the work and also to Dr. V. D. Nanoty, Principal, Shri Radhakisan Laxminarayan Toshniwal College of Science, Akola for providing necessary facilities.

\section{References}

1 Colak A T, Colak F, Atar A and Olgun A, Acta Chem Solv., 2010, 57(1), 212-221.

2 Rohini R, Reddy P M, Shanker K and Ravinder V, Acta Chem Solv., 2009, 56, 900.

3 Tozkoparan B, Gokhan N, Aktay G, Yesilada E and Ertan M, Eur J Med Chem., 2000, 35, 743-750.

$4 \quad$ Ikizler A A, Uzunali E and Demirbas A, Indian J Pharm Sci., 2000, 5, 289. 
$5 \quad$ Sadana A K, Mirza Y, Aneja K R and Prakash O, Eur J Med Chem., 2003, 38, 533-536.

6 Srinivas H, Ramakrishna I A and Arvind A N, Tetrahedron Lett., 2005, 46, 4585.

7 Mathew V, Keshavayya J, Vaidya V P and Giles D, Eur J Med Chem,. 2007, 42, 823-840.

8 Demirbas N, Demirbas A, Karaoglu S A and Celik E, ARKIVOC, 2005, 1, 75.

9 Kritsanida M, Mouroutsou A and Marakas P, I L Farmaco, 1996, 51, 659.

10 El-Khawass S M, Khalli M A and Hazzaa A A, I L Farmaco, 1989, 44, 703.

11 Al-Masoudi N A and Al-Soud Y A, Nucleos Nucleot Nucleic Acids, 2008, 279, $1034-$ 1044.

12 Arunkumar S, Iango K, Bairam R and Ramalakshmi N, Der Pharma Chem., 2009, 1, 70.

13 Mir I, Siddiqui M T and Comrie A, Tetrahedron, 1970, 26, 5235-5238.

14 Hester J B, Ludens J H, Emmert D E and West B E, J Med Chem., 1989, 32(6), 1157-1163.

15 Shah M H, Mhasalkar M Y, Palki M V, Deliwala C V and Sheth U K, J Pharm Sci., 1969, 58, 1398.

16 Holla B S, Veerndra B, Shivananda M K and Poojary B, Eur J Med Chem., 2003, 38, 759-767.

17 Dong H S, Onam B and Luo J D, Indian J Chem., 2002, 41(B), 1953.

18 Deohate P P and Berad B N, Indian J Chem., 2005, 44B, 638.

19 Deohate P P and Berad B N, J Indian Chem Soc., 2008, 85, 1050.

20 Deohate P P and Berad B N, J Indian Chem Soc., 2008, 85, 1153.

21 Barry A L, The Antimicrobial Suspectibility Test; Principle and Practices, Illus Lea \& Fibiger (Philadephia, Pa, USA), 180.

22 Kavanagh F, Analytical Microbiology, Academic Press, New York, 1963, 126.

23 Nishina C, Enoki N, Tawata S, Mori A, Kobayashi K and Fukushima, Agric Bio Chem., 1987, 51, 139.

24 Ananthanarayan R and Jagram Pancka G K, Text Book of Microbiology, $4^{\text {th }}$ Edn., Orient Longmans, 1990.

25 Colthup N B, Dally L H and Wiberly S E, Introduction to Infrared and Raman Spectroscopy, Academic Press, New York, 1964.

26 Silverstein R M, Bassler G C and Morrill T C, Spectrometric Identification of organic compounds, $4^{\text {th }}$ Edn., John Wiley \& Sons, New York, 1981. 